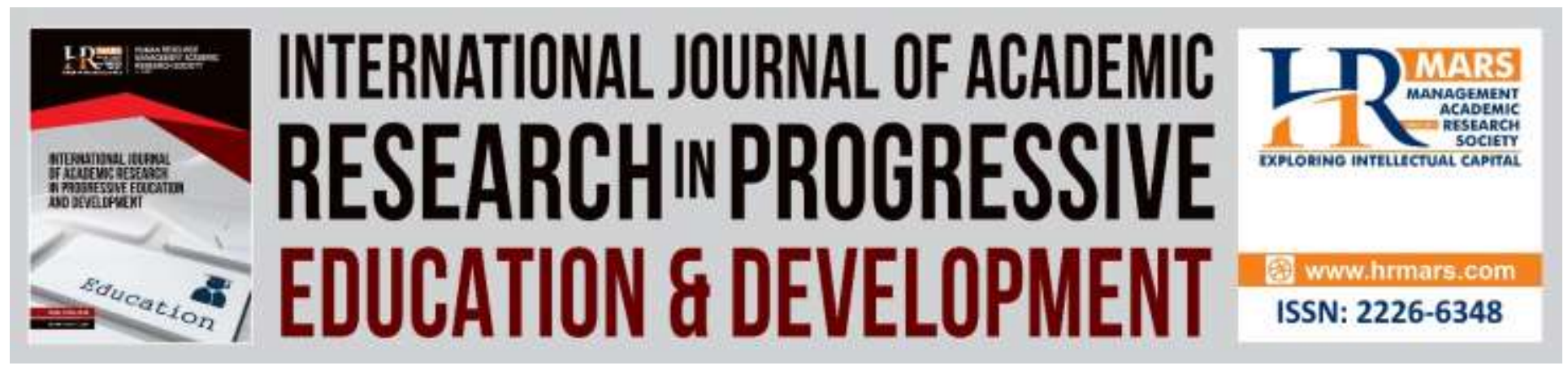

\title{
Overcrowded Classroom Problems Faced By School Teachers in District Muzzafarabad
}

\author{
Zul UI Ane Fatima, M. Mushatq, Qurat UI Ain Fatima
}

To Link this Article: http://dx.doi.org/10.6007/IJARPED/v8-i4/6530

DOI:10.6007/IJARPED/v8-i4/6530

Received: 11 October 2019, Revised: 20 October 2019, Accepted: 29 October 2019

Published Online: 12 November 2019

In-Text Citation: (Fatima, Mushatq, \& Fatima, 2019)

To Cite this Article: Fatima, Z. ul A., Mushatq, M., \& Fatima, Q. U. A. (2019). Overcrowded Classroom Problems Faced By School Teachers in District Muzzafarabad. International Journal of Academic Research in Progressive Education and Development, 8(4), 328-339.

Copyright: (C) 2019 The Author(s)

Published by Human Resource Management Academic Research Society (www.hrmars.com)

This article is published under the Creative Commons Attribution (CC BY 4.0) license. Anyone may reproduce, distribute, translate and create derivative works of this article (for both commercial and non-commercial purposes), subject to full attribution to the original publication and authors. The full terms of this license may be seen at: http://creativecommons.org/licences/by/4.0/legalcode

Vol. 8(4) 2019, Pg. 328- 339

http://hrmars.com/index.php/pages/detail/IJARPED

JOURNAL HOMEPAGE

Full Terms \& Conditions of access and use can be found at http://hrmars.com/index.php/pages/detail/publication-ethics 


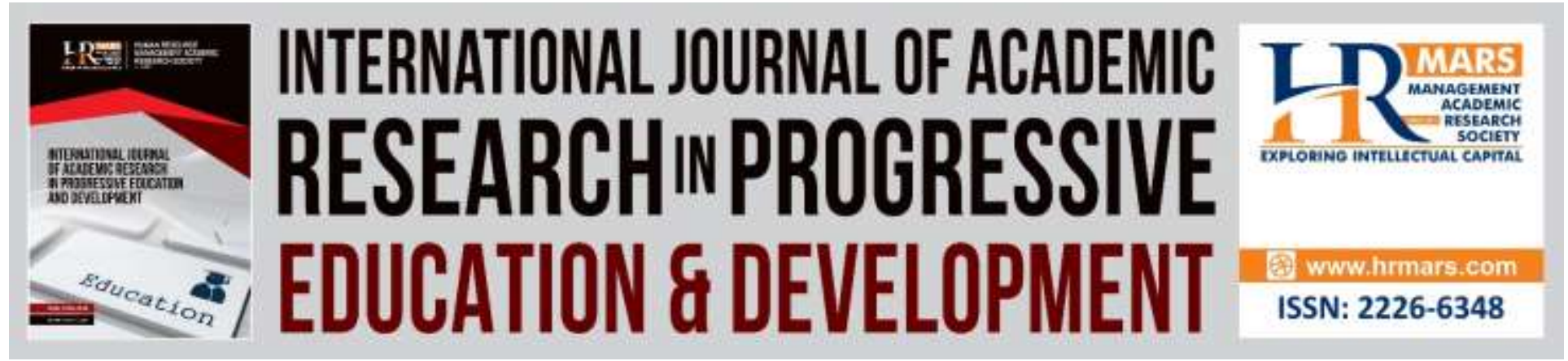

\title{
Overcrowded Classroom Problems Faced By School Teachers in District Muzzafarabad
}

\author{
Zul ul Ane Fatima, MPhil (Scholar) \\ Department of Education Wuaj \& K, Bagh \\ Email: syedaanie123@gmail.com \\ Dr. M. Mushatq \\ Assistant Professor Department of Education Wuajk \\ Email: dr.muhammad.mushtaq@wuajk.edu.pk,mushtaq.alvi@gmail.com \\ Qurat UI Ain Fatima \\ Department of English Wuaj \& K, Bagh. \\ Email: qurat.fatima89@gmail.com
}

\begin{abstract}
A very common problem in our education system is overcrowded classrooms, the idea of overcrowded classrooms envisaged large number of students as well as small space of the room, hence the study intends to find the problems teachers faced due to overcrowded classrooms. The major objectives were to find physical and academic problems teachers faced during classrooms. The population was teachers of government schools in Muzaffarabad district and sample was selected by using convenience sampling technique. The researcher developed a questionnaire and validated before its use, personally visited schools and collect data. After collection, data was analyzed by frequency and percentage method. The study found out that the discipline of the class, participation by students, evaluation by teachers and other physical problems do exists. It was recommended that a rationalization of the schools students just like teachers need to be made, physical barriers may be addressed and teachers may be provided trainings to handle large classes.
\end{abstract}

\section{Introduction}

Classroom is very important for the learning activities of school students. There is a lot of strength in the schools that's why classroom becomes overcrowded. My study based on the problems that teachers faced in the overcrowded classroom. 
Education is happening to the definition ventures of the 21st century with the crisis of globalization and worldwide culmination. In the quick changing and progressive world, instruction and innovation are the desired tools for respectable survival and achievement. Advancement and thriving of the nation relies upon the sort of instruction that is given to any nation or individuals. It is perceived face that without a base that without a base, instruction level for the whole populace of any nation, a human advancement procedure can't be sustained (Talib, 1996).

One of the main problems of our direction structure is that the understudy's students of the class were 40. The stuffed classes similarly impact the learning strategy of understudies in view of the fact, the quality of experienced in government schools and they cannot control the students. Stuffed classes instructor is less $s$ is additionally having bad influence on the conduct of the students (Happner, 2007).

Classroom is the most important territory inside of the school. The whole outline of classroom is appealing which mirrors the needs, objectives, theory, identity and showing style of understudies. Understudies learning conduct can be improved when educators set aside time to make classroom atmosphere in which youth feel great comfort with their instructors and associates. Be that as it may, lamentably, Pakistan the classroom are packed furthermore intelligent atmosphere does also not exist. (Hayes. 1997). Congestion gravely impact influence on instructor's workloads made distressing working condition for the educators and prompted higher instructor absent. Classroom condition not just make it challenges for the understudies to focus on their scores however unavoidable point of confinement can spend on creative showing routines, for example a co-agent learning gathering or without a doubt on the showing anything past the bosom least of required material also, in light of the fact that instructors should continually battle basically to keep up stuffed classroom, the probability build that they will experience the ill effects of burnout prior then may at generally be the situation. (Pedder, 2006). A Definite learning place is called classroom in which classes are held. All educational institutes including preschool to university have classroom. Other places where education \& training for students are provided have classroom such institute include religious, cooperation \& humanitarian organizations. The purpose of classroom is to provide a space for learning without the interruption by outside distraction. Class size refers to as number of students during a school year, for whom a teacher is primary responsible. Teacher is considering as owner of classroom and it is responsibility of the teacher to provide the instruction to the students in a convenient way. Class size is actually the number of students assigned to a specific teacher. (Shepard, 2000). Ratio of students to teachers is calculated as "ratio of total number of teachers at a school to complete enrollment of school". Such ratio is helpful to assign classes to different teachers. This may happen students to teacher's ratio may be small, but larger is the class size than what the ratio of students to teacher leads one to believe area (Renaud \& Tannenbaum, 2009). A small class is considered as a class having 11 or less than 11 students. A large class is defined as the one containing 20 or more students (Harmer, 2000). in 20 $0^{\text {th }}$ century john Dewy explained that class sizes should be very small in his ideal school. "For the purposes of convenience, the children are divided into small groups of eight to twelve according to the kind of work and the age of the 
children. It is expected that the teacher will give attention to the specific powers and deficiencies of each child, so that the individual capacities will be brought out, and individual limitations made good. (Woolner \& Pamela, 2010). For lessons that require specific resources or vocational approach different types of classrooms both indoors and outdoors are used. This allows for learning in an authentic context that fosters the natural development of the particular vocational skill. This is known as situated learning. Classrooms can range from small groups of five or six to big classrooms with hundreds of students. A large class room is also called a lecture hall. A few examples of classrooms are computer labs which are used for IT lessons in schools, gymnasiums for sports, and science laboratories for biology, chemistry and physics. There are also small group classrooms where students learn in groups of about 7 or less. Most classrooms have a large writing surface where the instructor or students can share notes with other members of the class. Traditionally, this was in the form of a blackboard but these are becoming less common in wellequipped schools because of new alternatives like flipcharts, whiteboards and interactive whiteboards. Many classrooms also have TVs, maps, charts, pencils, books, monographs and LCD projectors for presenting information and images from a computer. In the past, schools and institutions would often have one computer lab that served the entire school only at certain times of the week. Computers in the classroom itself in- crease interest in learning and awareness of the importance of what is being taught. Children are less likely to feel that a subject is archaic if the teacher uses new technological instructional techniques, "increasing the student's interest in learning something new". Integration of technology improves the capabilities of the students. (Hamasha, 2000).

Though all problems can't be handle at one time like overcrowded classroom. In some circumstances many problem seem to be very small but they badly disturb the teaching learning process. Mostly problems may arise during the activities when students finish their activity first and make noise than teacher face difficulty while controlling the class. Discipline is the first step in importing knowledge effectively. If the size of the class is small it is easy to maintain discipline but in overcrowded classroom it's seems to be impossible to maintain strict discipline.

yu (2004) both teachers and students feel uncomfortable in overcrowded classroom. They became hopeless and feel unhappy of the overall hostile situation. It becomes difficult for the teacher to keep proper eye contact with the students. This disturbs the teaching learning process badly. (Talib, 1996).

Although it is very difficult to carry out accurate assessment and evaluation of overcrowded class because their supervision, discipline an regulate their activities in class is highly complicated for a teacher, who is unable to provide effective feedback on the exercises done by the students in class or at home (Renaud, Tannenbaum \& Stantial, 2007).

In overcrowded class there is much noise, students can gossip, pay least attention to teachers who is already in turmoil and mental disturbance because he/she is unable to be heard, his voice dies in the class turmoil. It all slows down the learning process and teaching learning may be struck off (Sumera \& Mushtaq, 2017). 
Vol. 8, No. 4, 2019, E-ISSN: 2226-6348 @ 2019 HRMARS

The management structure of the class as well as school also play an important role in learning process as most of the class are joined to increase utility of the faculty that makes class rooms overcrowded, secondly the size of the room matters a lot that sometimes makes less number of students as a overcrowded class. The students teachers ratio may decrease this issue but some of the faculty doing other duties and they are on the strength of the teaching faculty can also be set side so that overcrowded class could be made manageable (Mushtaq, Sagir, Kayni \& Alim, 2015).

Another argument was raised as overcrowded classes may be handled and regulate by using symbolic learning model in the class as students most like to have visual presentations so if the large class rooms are equipped with multimedia and projectors or sound systems so that the students could hear the teachers well and gain access to the teacher and to be heard as well. (Mushtaq, Kayani \& Arif, 2015).

A reciprocal teaching techniques may also be used to lessen the difficulties of the crowded classrooms on the part of the teachers as he/ she may keep busy all the students in various teaching stages but the problem of noise and class chaos remained as it is, there is no solid solution to that issue, the various stages summarizing, questioning, clarifying and predicting all involved students participation so when students take part there must be noise and disturbance it depends on the teacher ability and skills how he manages himself and his class. Eclectic approach may be an effective way to overcome this issue perhaps. (Sumera, Mushtaq, 2017) Class is an effective connection between teachers and students either it is in formal and informal school, group and other places of interactions. The teacher conduct the act of learning by imparting of data, provide a chances of exercise and practice because the nature of teacher is knowledge sharing and providing guidance.

\section{Methodology}

The purpose of the study was to measure the "overcrowded classroom problem faced by school teachers in district Muzaffarabad". Research methodology include following steps.

\section{Population}

Population of current study consisted of all schools of district Muzaffarabad.

\section{Sample of Study}

The sample of present study was consisting of 200 teachers of district Muzaffarabad. Simple random technique was used.

\section{Research Instrument}

After studying relevant literature and getting help of expert's. Researcher herself composed a questionnaire for measuring over crowded classroom problems of teachers. The questionnaire consist of 19 items and each item is followed by 5 point liker scale regarding responses strongly agree, agree, strongly disagree, disagree, undecided. 
INTERNATIONAL JOURNAL OF ACADEMIC RESEARCH IN PROGRESSIVE EDUCATION AND DEVELOPMENT

Vol. 8, No. 4, 2019, E-ISSN: 2226-6348 @ 2019 HRMARS

\section{Data Collection}

The researcher personally visited the sample schools and distributed the questionnaire among the respondents. The researcher explained the all items of questionnaire to the respondents and then they filled it easily.

\section{Data Analysis}

After the collection of the data it was tabulated, analyses and interpreted in the form of frequencies and percentages.

\section{Results}

Teacher face problem in managing discipline in overcrowded class.

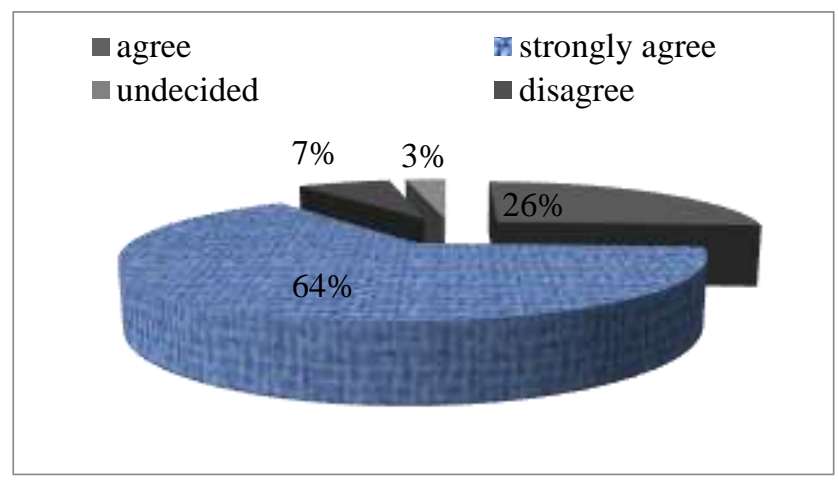

Graph No.1 shows that total 64\% respondents strongly agree and $26 \%$ respondents agreed with the statement of the question. "teacher face problem in managing discipline in overcrowded class." Only 7\% disagree with this statement and 3\% teacher strongly disagree with this statement.

Students unable to focus attention in overcrowded classroom.

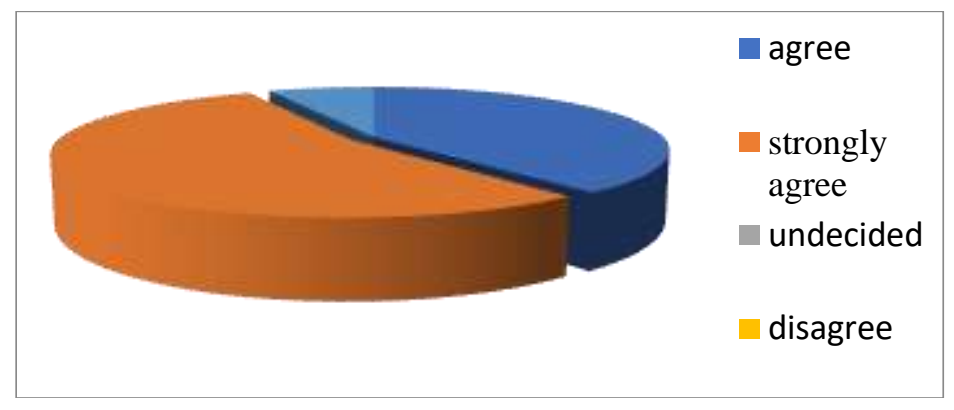

Graph No.2 shows that total 54\% respondents strongly agreed and 39\% respondents agreed with the statement of the question. "teacher faces difficulty to focus on students who are not paying attention in overcrowded classroom". Only 7\% disagree with this statement.

A good environment can reduce the problems in overcrowded classroom. 


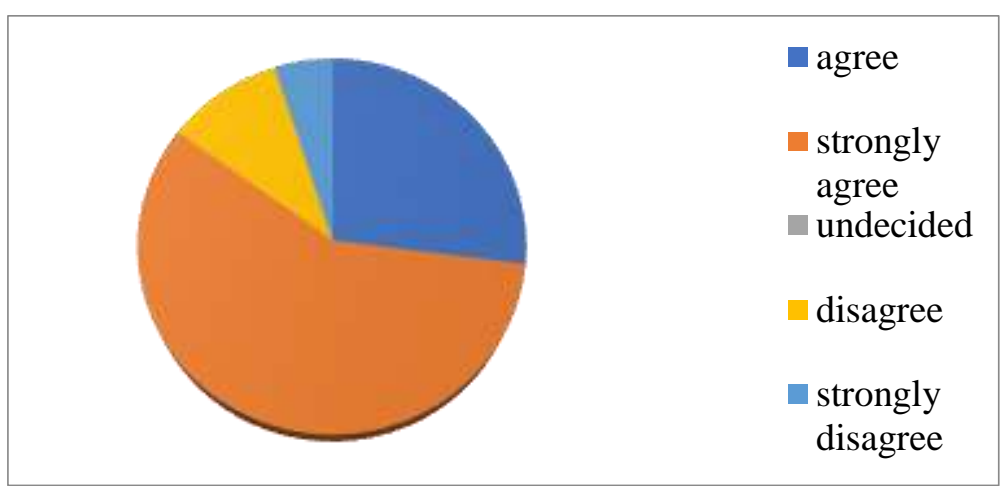

Graph No.3 shows that total 58\% respondents strongly agreed and $27 \%$ respondents agreed with the statement of the question. "a structure of good environment can reduce the number of problems that teacher face in overcrowded classroom". Only $10 \%$ respondents disagree and $5 \%$ respondents strongly disagree with this statement.

Teacher faces problem in securing students total attention during lesson in overcrowded class.

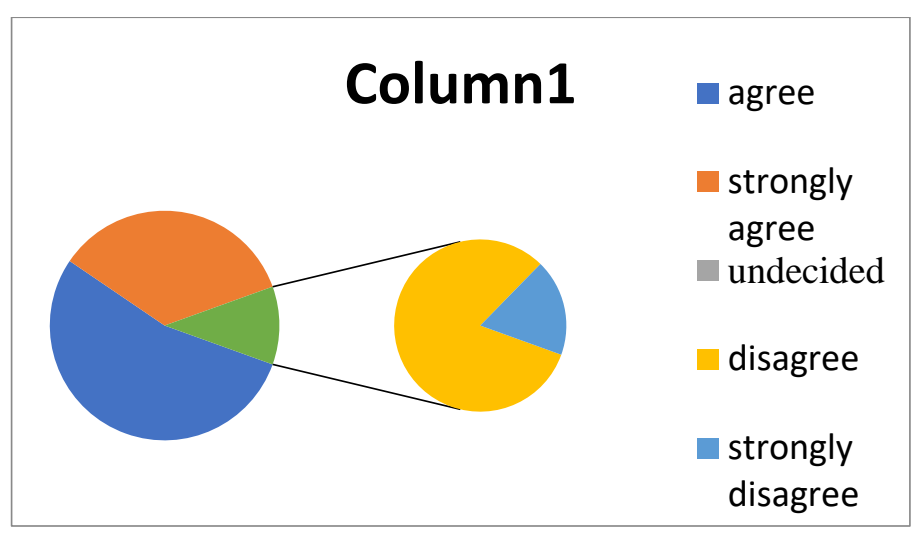

Graph No.4 shows that total 35\% respondents strongly agreed and 54\% respondents agreed with the statement of the question. "Teacher faces problem in securing students total attention during lesson in overcrowded class". Only 9\% respondents disagree and $2 \%$ respondents strongly disagree with this statement.

Students face physical problems (Voice Listening and Question) in overcrowded class. 
INTERNATIONAL JOURNAL OF ACADEMIC RESEARCH IN PROGRESSIVE EDUCATION AND DEVELOPMENT

Vol. 8, No. 4, 2019, E-ISSN: 2226-6348 @ 2019 HRMARS

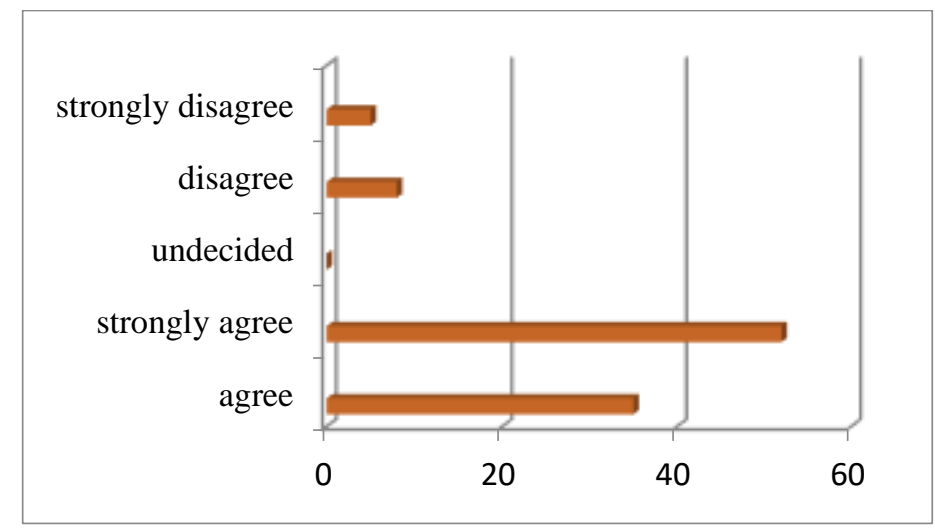

Graph No.5 shows that total 52\% respondents strongly agreed and 35\% respondents agreed with the statement of the question. "students face physical problems (voice listening and question) in overcrowded class". Only $8 \%$ respondents disagree and $5 \%$ respondents strongly disagree with this statement.

Teachers face difficulty in sitting arrangement in overcrowded classroom.

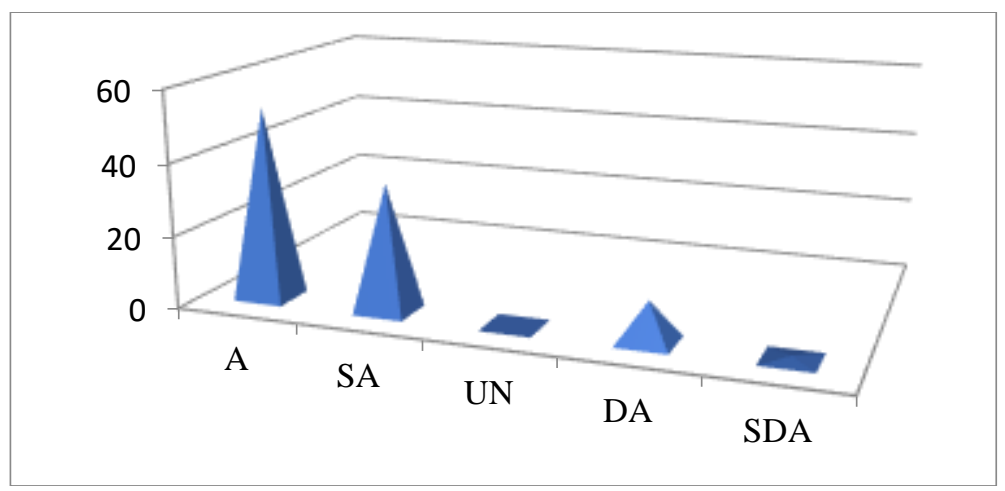

Graph No.6 shows that total 35\% respondents strongly agreed and 53\% respondents agreed with the statement of the question. "teachers face difficulty in sitting arrangement in overcrowded classroom". Only $11 \%$ respondents disagree and $1 \%$ respondents strongly disagree with this statement.

Students face difficulty to raise question in overcrowded classroom. 
INTERNATIONAL JOURNAL OF ACADEMIC RESEARCH IN PROGRESSIVE EDUCATION AND DEVELOPMENT

Vol. 8, No. 4, 2019, E-ISSN: 2226-6348 @ 2019 HRMARS

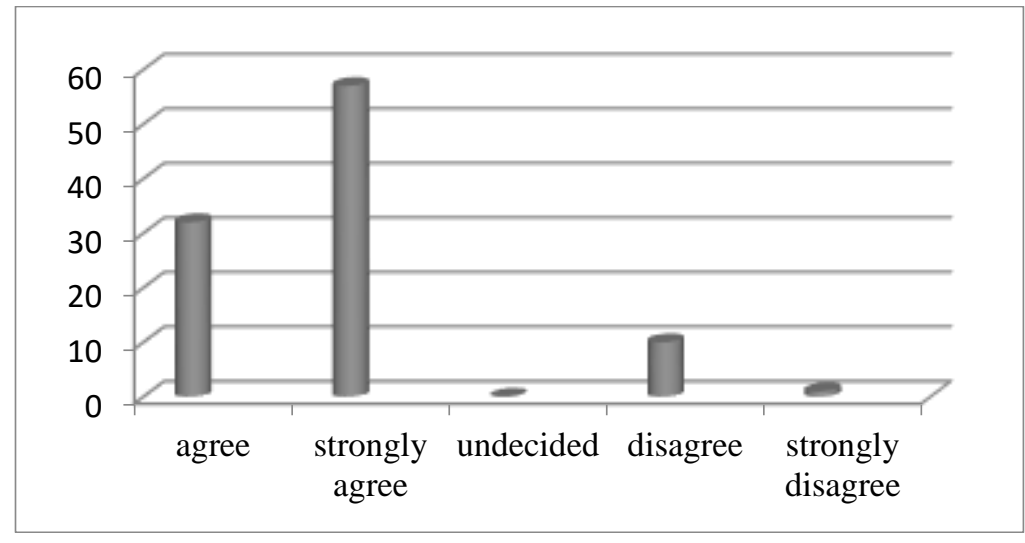

Graph No.7 shows that total 57\% respondents strongly agreed and 32\% respondents agreed with the statement of the question. "students face difficulty to raise question in overcrowded classroom" only $10 \%$ respondents disagree and $1 \%$ respondents strongly disagree with this statement.

Weak students are not participating in all activities in overcrowded classroom.

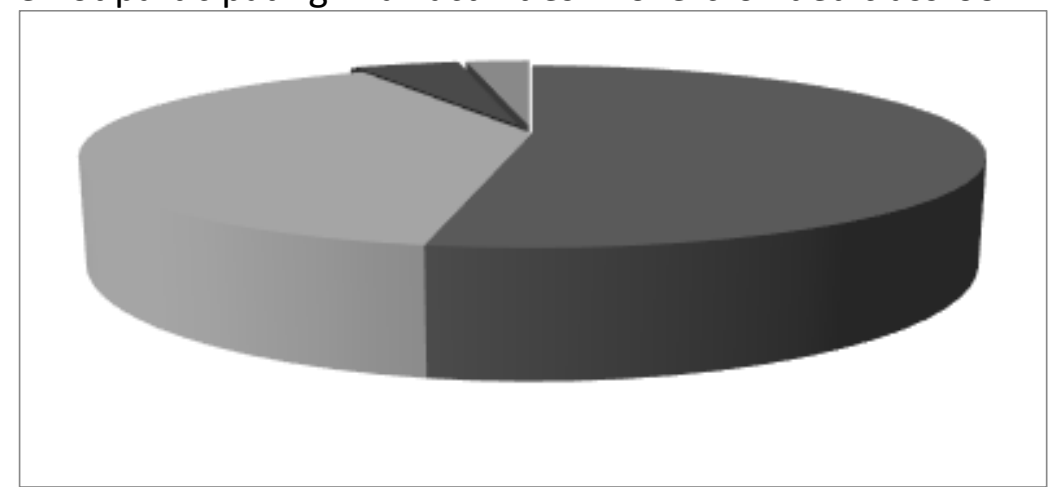

Graph No.8 shows that total $40 \%$ respondents strongly agreed and $54 \%$ respondents agreed with the statement of the question. "weak students are not participating in all activities in overcrowded classroom" only $5 \%$ respondents disagree and $3 \%$ respondents strongly disagree with this statement.

The students are not able to get every point not the teacher in overcrowded classroom.

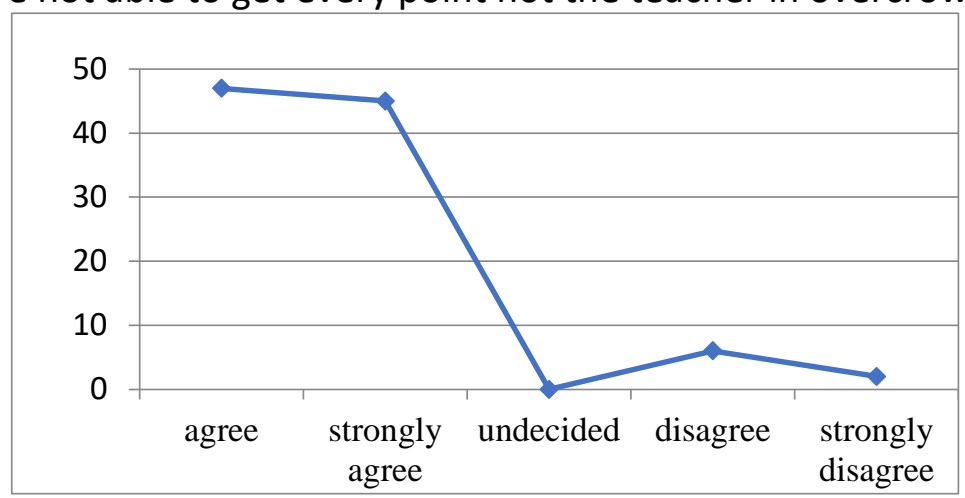


Vol. 8, No. 4, 2019, E-ISSN: 2226-6348 @ 2019 HRMARS

Graph No.9 shows that total $45 \%$ respondents strongly agreed and $47 \%$ respondents agreed with the statement of the question. "the students are not able to get every point not the teacher in overcrowded classroom". Only $6 \%$ respondents disagree and $2 \%$ respondents strongly disagree with these statements

Teacher face problem of evaluation in overcrowded classroom.

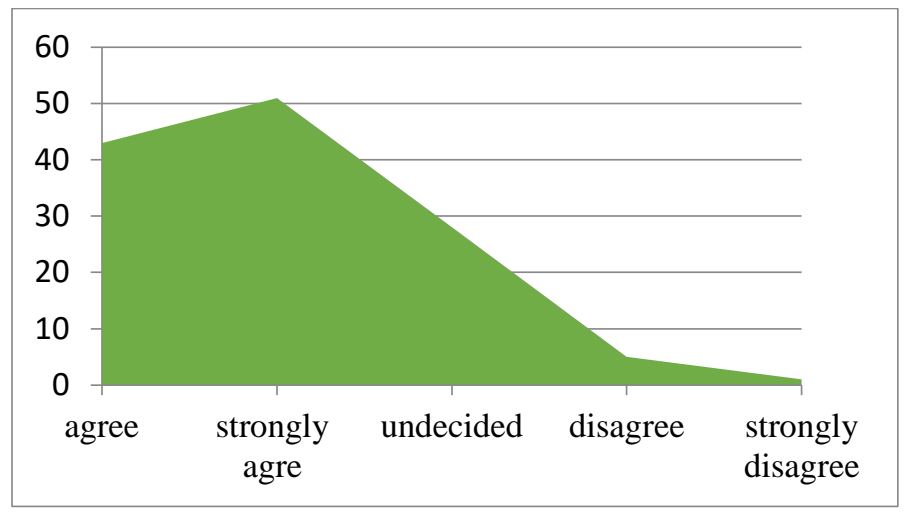

Graph No.10 shows that total 51\% respondents strongly agreed and $43 \%$ respondents agreed with the statement of the question. "teacher face problem of evaluation in overcrowded classroom." Only 5\% respondents disagree and $1 \%$ respondents strongly disagree with this statement

it is difficult to provide feedback on student's assignment in overcrowded classroom.

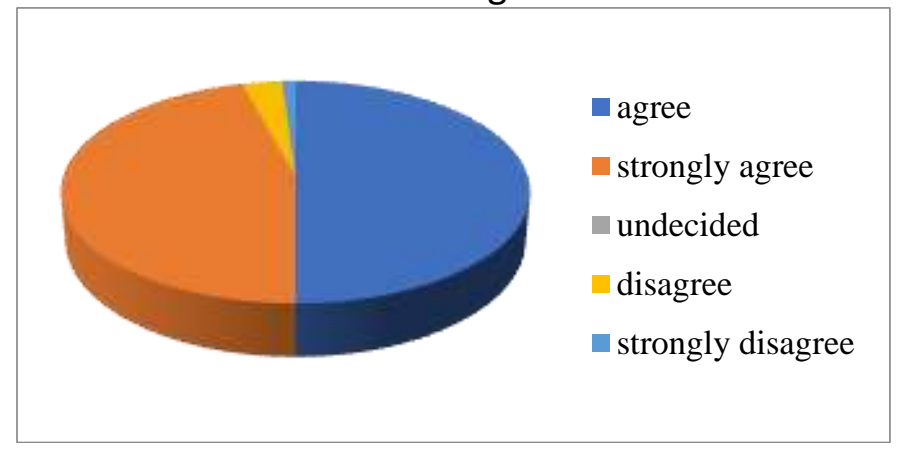

Graph no.11 shows that total $43 \%$ respondents strongly agreed and $47 \%$ respondents agreed with the statement of the question. "it is difficult to provide feedback on student's assignment in overcrowded classroom." Only $3 \%$ respondents disagree and $1 \%$ respondents strongly disagree with this statement.

\section{Finding of the Study}

1. As indicated the teachers face problem of management of the discipline in the class so the whole time is wasted in managing class while teaching learning get secondary place (Graph 1)

2. The teachers were agreed that the teachers feel very difficult to get students focus because they don't pay attention due overcrowded class. (Graph no 2)

3. Teacher agreed that a structure of good environment can reduce the number of problems that teacher face in overcrowded classroom. (Graph no 3) 
INTERNATIONAL JOURNAL OF ACADEMIC RESEARCH IN PROGRESSIVE EDUCATION AND DEVELOPMENT

Vol. 8, No. 4, 2019, E-ISSN: 2226-6348 @ 2019 HRMARS

4. Most of the teachers agreed that they faces problem in securing students total attention during lesson in overcrowded class. (Graph no 4)

5. Most of the teachers agreed that students face physical problems (voice listening and question) in overcrowded class. (Graph 5)

6. Most of the teachers agree that teachers face difficulty in sitting arrangement in overcrowded classroom. (Graph 6)

7. Most of the teachers agreed that students face difficulty to raise question in overcrowded classroom. (Graph 7)

8. Most of the teachers agreed that the students are not able to get every point of the teacher in overcrowded classroom. (Graph 8)

9. Many of the teachers agreed that teacher face problem of evaluation in overcrowded classroom. (Graph 9)

10. Most of the teachers agreed that it is difficult to provide feedback on student's assignment in overcrowded classroom. (Graph 10)

\section{Conclusions}

Overcrowded classes is a huge problem in our school and college education systems that affect student's teachers and administration. as mentioned in above study majority of the problems faced by the teachers himself/herself in all the stages of teaching and learning process. the problems included are discipline, noise, conducting evaluation, getting students attention, control the class, teachers' voice, students questioning, and siting arrangement and obtaining full attentions of the class. Teachers are always struck in providing feedback on the assignment. The research is significant in Pakistan particularly in Azad Jammu \& Kashmir because the schools are situated at far flung areas so a large population depends on them, the study focuses on problems and their solution that would definitely benefit them. it was also helpful for government to rationalize the schools and students and allocation of the as per population of the areas. The

emergence of media like speaker and multimedia could help reduce this barrier so solar energy based gadgets could be installed to minimize these problems. 
INTERNATIONAL JOURNAL OF ACADEMIC RESEARCH IN PROGRESSIVE EDUCATION AND DEVELOPMENT

Vol. 8, No. 4, 2019, E-ISSN: 2226-6348 @ 2019 HRMARS

\section{References}

Talib, A. S. (1996) Control and Address the Problems of Students in the Classroom. Amman Dar Alifiker

Happner, F. (2007). Teaching the large college class. San Francisco: Jossey-Bass.

Hayes, U. (1997). Helping teachers to cope with large classes. ELT Journal, 31-38.

Hamasha, S. (2000) Administrative Problems Facing the Newly Appointed Teachers in The First three grades in irbid government schools. MA. Thesis, Unpublished, Irbid: Yarmouk University.

Harmer, J. (2000). How to teach English. Foreign Language Teaching and Research Press.

Hayes, D. (1997). Helping teachers to cope with large classes. ELT journal, 51(2), 106-116.

Mushtaq, M., Kayani, M. M., \& Arif, M. H. (2015). Symbolic Learning through Information and Communication Technology in Pakistani Universities: Prospects and Possibilities. Mediterranean Journal of Social Sciences, 6(5), 35-43

Mushtaq, M., Saghir, A. R., Kayani, M. M., \& Alam, M. T. (2015). A Study of Relationship of Management Structures in Private Schools and Their Performance in Board Examinations at Secondary Level. 230-242

Pedder, D. (2006). Are small classes better? Understanding relationships between class size, classroom processes and pupils" learning. Oxford Review of Education, 32(2), 213-234.

Renaud, S., Tannenbaum, E., \& Stantial, P. (2007). Students-centered teaching in large classes with limited resources. English Teaching Forum, 45(3), 251-273.

Shepard, L. A. (2000). The role of assessment in a learning culture. Eductional researcher, 29 (7), 4-14.

Sumera, M., Mushtaq, M. (2017) Effectiveness of Reciprocal Teaching versus Traditional Teaching, Ponte International Journal of Sciences and Research, Rome Italy, Vol. 73 (5) 135159

Yu, J. (2004). Problems and strategies of teaching English in large college classes. Journal of Chongqing University of Post and Telecommunication (Social Science), 3(1), 139-140.

Zhang, M. (2008). Challenges and solutions of teaching large classes. Education science and Culture magazine, 29 (68-69) 